the old days, a mere three years between writing and publication would barely have been noticed.

The author, one of the leading lights in the modern phase of scrapie research, and a member of the powerful research group at the Institute for Research on Animal Diseases, Compton, has written a useful survey of the present state of the art and shows us how today's biochemists, geneticists and cell biologists are tackling the problems. Scientists who work with scrapie need to be imaginative and optimistic, yet prepared for long waits and set-backs; seers, but at the same time stoics. Theirs is a difficult path, and they are to be admired for their dogged pursuit of truth through the scrapie labyrinths.

Understanding scrapie will be of more than academic interest. Scrapie remains an important disease of sheep, and man also is infected by closely similar transmissible agents, causing kuru and Creutzfeld-Jacob disease. Both are rare but both are fatal, and when we understand the pathogenesis of scrapie these, too, will be understood. Doubtless we shall then also be in a better position to understand the origins of various other chronic diseases of man.

C. A. Mims

\title{
Epidemiology and infections
}

By C. E. Gordon Smith. 1976. Patterns of progress (microbiology) series. Shildon (Co. Durham): Meadowfield Press Ltd. Pp. vi and 50. £1.90.

Dr Gordon Smith has given us a very broad and useful survey of epidemiology and infections. He has successfully avoided the miasma of generalities and definitions that dismay and discourage the occasional reader of epidemiology texts, and has instead concentrated on the solid meat of examples and phenomena. Undaunted by the prodigious area to be covered, he has made his short book eminently readable, and given a well balanced survey of a fascinating subject. The writing is at times hurried, and one can always point out omissions and errors, but this reviewer learnt about several interesting epidemiological happenings, and hopes that this book will have a wider readership.

$$
\text { C. A. Mims }
$$

\section{Essentials of bacterial and viral genetics}

By D. M. Carlberg. 1976. Springfield, Illinois: Charles C. Thomas. Pp. xv and 320. US $\$ 24.75$.

This is a very readable book, covering, as the title claims, the essentials of microbial genetics though an undergraduate in microbiology would certainly have to consult more detailed texts. It is commendable for its historical approach and also for devoting two chapters to mutations, a subject vital to the study of genetics. The mention of industrial applications is useful, as well as the reference to genetic engineering.

The first chapter summarises the laws of genetics, and this is followed by a chapter on the structure and replication of DNA, and by one on protein synthesis and control mechanisms. The two chapters on mutation are next. The last third of the book deals with the genetic mechanisms of bacteria, the properties and genetics of bacteriophages, plasmids (it was pleasing to see the retention of the term "episome "), and briefly with eucaryotic organisms, including fungi, algae, protozoa, higher plants and man. A valiant attempt is made to provide a limited bibliography for each chapter. This is a good, digestible introduction to the subject.

L. O. ButLER

\section{Microbial response to mild stress}

By R. E. Strange. 1976. Shildon, Co. Durham: Meadowfield Press, Ltd. Pp. viii and 83. $£ 2 \cdot 80$.

This small book is one of the series "Patterns of progress" published under the general editorship of Dr J. Gordon Cook. A " mild stress" is defined in this book as being one that results in some or no loss of microbial viability, and damage that may be partly or completely 